\title{
WATER SALINITY AND INITIAL DEVELOPMENT OF YELLOW PASSION FRUIT
}

\author{
Frederico Antônio Loureiro Soares ${ }^{1}$; Hans Raj Gheyi ${ }^{1,4 *}$; Sergio Batista Assis Viana ${ }^{1,4}$; Claudio \\ Augusto Uyeda ${ }^{3,4}$; Pedro Dantas Fernandes ${ }^{2}$ \\ ${ }^{1}$ Pós-Graduando do Depto. de Engenharia Agrícola - DEAg - CCT/UFPB \\ ${ }^{2}$ Depto.de Engenharia Agrícola - DEAg - CCT/UFPB, Av. Aprígio Veloso, 882 - C.P 10.056 - CEP: 58109-970 - \\ Campina Grande, $P B$ \\ ${ }_{4}^{3}$ Graduando em Engenharia Agrícola - UFPB \\ ${ }^{4} \mathrm{CNPq}$ Fellow \\ *Corresponding author<hans@deag.ufpb.br>
}

ABSTRACT: Considering the lack of information on salt tolerance of passion fruit (Passiflora edulis) seedlings, a study was carried out to evaluate the effects of water salinity on the vigor and initial growth in a completely randomized design with 8 levels of electrical conductivity of irrigation water $\left(E C_{w}\right)$, varying from 1.0 to $8.0 \mathrm{dS} \mathrm{m}^{-1}$. Salinity delayed the germination process, but relative reduction was observed only above $\mathrm{EC}_{\mathrm{w}} 4.43 \mathrm{dS} \mathrm{m}^{-1}$. Seedling vigor and growth decreased with increasing salinity, however, water at $4 \mathrm{dS} \mathrm{m}^{-1}$ resulted in $85 \%$ of vigor and seedlings with more than $50 \%$ growth in comparison to the lowest salinity treatment. Based on soil salinity, the passion fruit may be considered as 'moderately tolerant' to salinity during the initial phase.

Key words: Passiflora edulis, salinity tolerance, electrical conductivity

\section{SALINIDADE DA ÁGUA E DESENVOLVIMENTO INICIAL DO MARACUJAZEIRO AMARELO}

\begin{abstract}
RESUMO: Considerando-se a inexistência de indicativos de tolerância do maracujazeiro (Passiflora edulis) à salinidade, estudaram-se, no delineamento inteiramente casualizado, os efeitos de oito níveis de condutividade elétrica da água de irrigação (CEa), variando de 1,0 a 8,0 dS $\mathrm{m}^{-1}$, sobre o vigor e a formação de mudas de maracujazeiro amarelo. A salinidade retardou a germinação, mas só houve decréscimo relativo com CEa > $4,43 \mathrm{dS} \mathrm{m}^{-1}$; o vigor de plântulas e o crescimento foram afetados com a salinidade, todavia, água de CE de 4 dS $\mathrm{m}^{-1}$ proporcionou $85 \%$ de vigor e mudas com crescimento superior a $50 \%$ em relação ao menor nível estudado. Com base na salinidade do solo, o maracujá amarelo pode ser considerado 'moderadamente tolerante' na fase de muda.

Palavras-chave: Passiflora edulis, tolerância, condutividade elétrica
\end{abstract}

\section{INTRODUCTION}

Fruit cultivation under irrigated condition in northeastern Brazil has increased considerably during the last decades, mainly due to the excellent temperature and insolation conditions. The Brazilian Government, during next five years, expects to establish 100,000 to 150,000 ha per year of irrigated fruit crops, under the auspicious Program for Support and Development of Irrigated Fruit Cultivation in the Northeast - PADFIN (Brasil, 1998). In 1997, the irrigated area in the region was already close to 400,000 ha, with the potential for nearly 6 million ha (Bernardo, 1997). However, Chile, which has a total irrigated area of 220,000 ha, is the leader in global fruit export, with an annual exchange of about US\$ 1.4 billion (Brasil, 1998).

Due to the expected increase in irrigated area in the Northeast and scarcity of good quality water in the region, the use of marginal quality water, from the salinity/ sodicity point of view, has become a necessity in any irrigation program. This, associated with inadequate soilwater-plant management and edaphoclimatic conditions, has promoted soil salinization, jeopardizing crop yields, and even causing the abandonment of formerly productive areas. In 1983, there were already about 8.5 million ha affected by salinity and related problems in the region (Pereira, 1983).

The inhibition of crop growth under saline conditions is commonly caused by osmotic effect and/or due to excessive ion accumulation in the plant tissues, which may cause ionic toxicity and/or nutritional imbalance (Boursier \& Lauchli, 1990). The extent to which each stress condition affects plant growth/development, however is dependent on various factors, including plant species, cultivar and phenological stage, soluble salt composition, stress intensity and its duration, and edaphoclimatic conditions (Cramer et al., 1994).

Each plant material has a salinity tolerance limit, above which the yield reduces linearly (Maas, 1984; Ayers \& Westcot, 1991). This limit is called salinity threshold (ST). These authors classified the passion fruit as sensitive to salinity, crops with $\mathrm{ST}<1.3 \mathrm{dS} \mathrm{m}^{-1}$. However, the precise ST value or rate of yield reduction as a function of salinity increase has not been mentioned. Based on the relationship between electrical conductivity of irrigation water $\left(\mathrm{EC}_{\mathrm{w}}\right)$ and electrical conductivity of 
saturation extract of soil $\left(\mathrm{EC}_{\mathrm{se}}\right)$, as proposed by Ayers \& Westcot (1991), for a leaching fraction between 0.15 and 0.20 , the threshold value in terms of water salinity $\left(E C_{w}\right)$ would be around $0.9 \mathrm{dS} \mathrm{m}^{-1}$.

Because of the magnitude of salinity problems in Brazilian Northeast region, as well as the importance of passion fruit for the region (40\% of national production), and the lack of information about threshold salinity indicators for passion fruit, the objective of this study was to evaluate the effects of irrigation water salinity on passion fruit seedling vigor and growth.

\section{MATERIAL AND METHODS}

The experiment was carried out from December 1999 to March 2000, in a greenhouse at the Department of Agricultural Engineering, Campus II - Federal University of Paraíba (UFPB), in Campina Grande, PB, Brazil (latitude: $7^{\circ} 15^{\prime} 18^{\prime \prime} \mathrm{S}$; longitude: $35^{\circ} 52^{\prime 2} 28^{\prime \prime} \mathrm{W}$; altitude: $550 \mathrm{~m}$ ).

The effects of eight levels of electrical conductivity of irrigation water $\left(E C_{w}\right)$ on the initial development of yellow passion fruit (Passiflora edulis Sims. f. flavicarpa Deg) until 77 days after sowing (DAS) were evaluated. Water salinity levels varied from 1 to 8 dS $\mathrm{m}^{-1}$ ( $\mathrm{N}_{1}$ to $\mathrm{N}_{8}$ respectively), and a randomized complete block design was used.

The substrate used was a mixture of three parts of soil + one part of earthworm humus on weight basis. The soil was a sandy-loam (0 - $0.2 \mathrm{~m})$, non-saline and non-sodic Oxisol, pH 5.4, from Nova Floresta - PB, the most important passion fruit producing municipality in the State of Paraíba.

Plastic pots $(0.25 \mathrm{~m}$ high and $0.1 \mathrm{~m}$ in diameter $)$ were drilled at the bottom for drainage, and were filled with $1.9 \mathrm{~kg}$ of the substrate. At $0.015 \mathrm{~m}$ depth, 10 seeds were sown in each recipient. At 16 DAS, the first thinning was performed, when only the two most vigorous seedlings were left. At 32 DAS, the second thinning was done, leaving one plant per pot. Until 32 DAS, pots were kept inside plastic trays, randomly distributed, and the water drained from six replications from each treatment was collected. After 32 DAS, the drainage water was collected from each pot separately, by coupling a collector pot at the bottom of each one.

Irrigation waters were prepared by adding $\mathrm{NaCl}$, $\mathrm{CaCl}_{2} \cdot 2 \mathrm{H}_{2} \mathrm{O}$ and $\mathrm{MgCl}_{2} \cdot 6 \mathrm{H}_{2} \mathrm{O}$ to the tap water, in a way to obtain the specific $E C_{w}$ for each treatment, keeping $\mathrm{Na}: \mathrm{Ca}: \mathrm{Mg}$ proportion as $7: 2: 1$, the proportion valid for most irrigation waters in northeastern Brazil (Medeiros, 1992).

Pots were irrigated every other day, and the volume applied intended to supply the evapotranspiration requirements and provide a leaching of about $40 \%$. The evapotranspiration or water consumption was determined by the difference between the volume applied and the volume drained.
Starting at 46 DAS, $10 \mathrm{~mL}$ of solution containing $4,5 \mathrm{~g} \mathrm{~L}^{-1}$ of soluble fertilizer (19:19:19) was applied every other day to each pot. The fertilizer solution contained also $\mathrm{Fe}, \mathrm{Mn}, \mathrm{B}, \mathrm{Zn}, \mathrm{Cu}$ and Mo, at 1000, 500, 200, 150, 110 and $70 \mathrm{mg} \mathrm{kg}^{-1}$, respectively. Substrate samples were collected at 32 and 77 DAS to evaluate the saturation extract salinity according to method suggested by EMBRAPA (1997).

The seed vigor was evaluated by determining the germination percentage (GP), using 12 repetitions, at 11 and 16 DAS; and seedling vigor was evaluated using 2 replications, by means of shoot dry matter (DMS) and root (DMR). The evaluations of initial development of passion fruit were performed at 32 DAS, using 2 replications, and at 77 DAS, using 4 repetitions. Besides the DMS and DMR, these evaluations included: number of leaves (NL), and plant height $(\mathrm{PH})$. At $77 \mathrm{DAS}$, the evaluation also included stem diameter at the root-shoot junction (SD) and leaf area (LA) estimated on the basis of previously established relationship between the weight of leaf discs of known area and the weight of the whole leaf.

Mineral composition of leaves and roots ( $\mathrm{Na}, \mathrm{Ca}$, $\mathrm{Mg}$ and $\mathrm{K}$ content) was measured at $77 \mathrm{DAS}$ using the method described by Malavolta et al. (1997); $\mathrm{Na}$ and K were quantified by flame photometry and $\mathrm{Ca}$ and $\mathrm{Mg}$ by atomic absorption spectrophotometry. The relative water consumption was also evaluated up to 32 DAS and from 33 to 77 DAS.

Statistical analyses to explain salinity effects included analysis of variance (Ferreira, 1996) and linear, quadratic and piece meal regression analysis.

\section{RESULTS AND DISCUSSION}

\section{Seed vigor}

Irrigation water salinity affected $(P<0.01)$ germination percentage (GP), quadratically in both periods (11 and 16 DAS) (Figure 1A). A lengthening of the germination period was observed, mainly above $\mathrm{N}_{5}$ level. At 11 DAS, GP decreased abruptly with increasing $E C_{w}$. In relation to $N_{1}$, the decrease in germination was $41.2 \%$ for $\mathrm{N}_{5}$ and $90.6 \%$ for $\mathrm{N}_{8}$. At 16 DAS, the relative decrease in GP occurred only for $\mathrm{EC}_{\mathrm{w}}$ values higher than $4.43 \mathrm{dS} \mathrm{m}^{-1}$.

The most important salinity effect was the extension of the germination period, 5 days on average, since the relative decrease due to the highest $\mathrm{EC}_{\mathrm{w}}$ level $\left(\mathrm{N}_{8}\right)$, at 16 DAS $(39.6 \%)$, was similar to that at the $\mathrm{N}_{5}$ level, at 11 DAS.

Further, in high salinity treatments $\left(\mathrm{N}_{7}\right.$ and $\left.\mathrm{N}_{8}\right)$, seed germination was observed up to 24 DAS, although it was not taken in to consideration. Since more than $80 \%$ of germination occurring at the lowest salinity level was observed with $\mathrm{EC}_{\mathrm{w}} 6.7 \mathrm{dS} \mathrm{m}^{-1}$, the salinity tolerance of yellow passion fruit is quite evident at this stage.

Excessive amounts of soluble salts in the soil cause a decrease in osmotic potential and consequently, a decrease in the water potential gradient between soil 
and seed. This makes difficult water absorption by the seed (Pizarro, 1985). Depending on the saline stress intensity, it may cause delay of the germination period, as observed in this study up to $\mathrm{EC}_{\mathrm{w}} 4.43 \mathrm{dS} \mathrm{m}^{-1}$, or inhibition of the germination process. Moreover, the excessive absorption of ions such as $\mathrm{Na}$ and $\mathrm{Cl}$ causes a decrease in respiration and in the activity of some enzymes involved in germination (Azimov, 1973), limiting the availability of energy for the cell division process and embryonic axis development.

\section{Initial seedling development}

Seedling development (16 DAS) decreased linearly with increasing irrigation water salinity. Figure 1B presents the regression equations (significant at 0.01 level of probability) obtained when relating DMS and DMR production to $\mathrm{EC}_{\mathrm{w}}$. Evaluation of seedling development shows a higher salinity effect on roots, DMS decreased $3.90 \%$ per unit increase of $\mathrm{EC}_{w}$ in relation to $\mathrm{N}_{1}(100 \%)$, while DMR decreased $5.33 \%$ on average. Similar effects have been observed in other studies on different crops, for example: Marinho et al. (1998) in pineapple; Souza (1999) in melon and watermelon, although some authors (Maas \& Hoffman, 1977; Shannon, 1997) have referred that salinity affected root system less than aerial parts.

Two factors have to be taken in account while studying plant tolerance to salinity: the salinity threshold (ST), level at which deleterious effects over plant growth/ development commence, and rate of decrease, when salinity levels are above ST values.
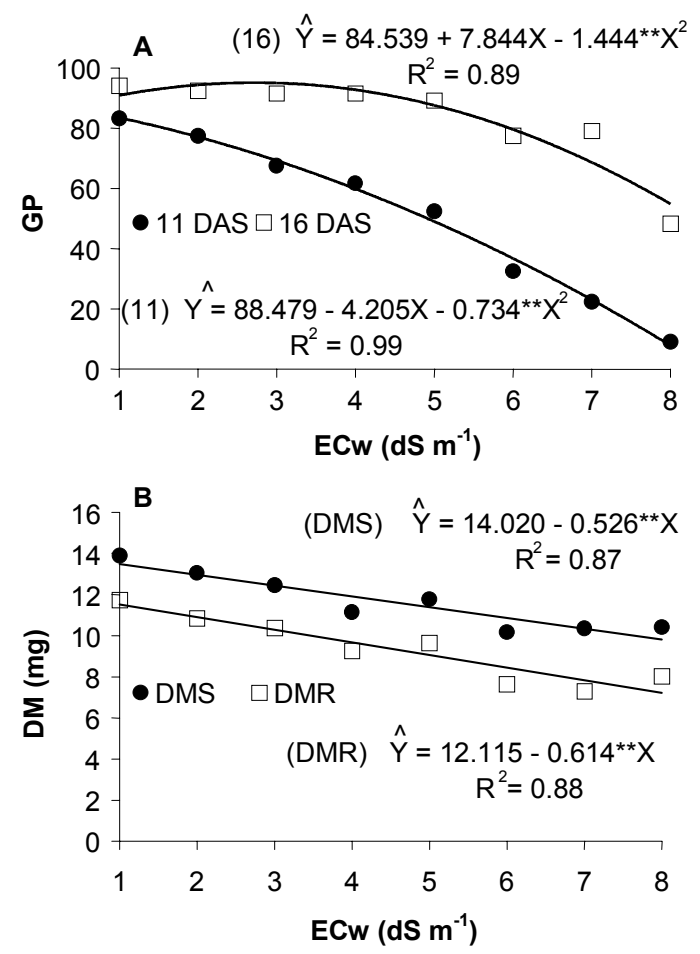

Figure 1 - Germination percentage (GP) at 11 and 16 days after sowing - DAS (A) and dry matter of shoot (DMS) and root $(\mathrm{DMR})$ at $16 \mathrm{DAS}(\mathrm{B})$ as a function of water salinity $\left(\mathrm{EC}_{\mathrm{w}}{ }^{1}\right)$. ${ }^{1} \mathrm{EC}_{\mathrm{w}}=1,2, \ldots, 8$ refer to salinity levels $\mathrm{N}_{1}, \mathrm{~N}_{2}, \ldots, \mathrm{N}_{8}$, respectively.
In this study, although the $\mathrm{EC}_{\mathrm{w}}$ restricted seedling growth starting at the lowest salinity level $\left(1.0 \mathrm{dS} \mathrm{m}^{-1}\right)$, the decrease rate observed was quite small (Figure 1B). Thus, at high salinity level, $8 \mathrm{dS} \mathrm{m}^{-1}$ e.g., $72.7 \%$ of DMS and $63 \%$ of DMR were obtained, in relation to $\mathrm{N}_{1}$ level. These results show the tolerance to salinity of yellow passion fruit during seedling emergence phase, mainly when salinity level is lower than $4 \mathrm{dS} \mathrm{m}^{-1}$. At this level, the relative accumulation of plant matter was above $85 \%$, in relation to $\mathrm{N}_{1}$. A possible explanation may be that as salinity extended the germination period, the majority of the seeds, at the highest salinity levels studied, germinated between 11 and 16 DAS (Figure 1A), partially justifying the lower DMS and DMR at 16 DAS for these treatments.

Several studies show the deleterious effects of salinity over the vigor of other crops (Souza, 1999; Viana, et al., 2001; and others). The effects are of physiochemical nature: physical, since the salinity decreases osmotic potential of soil solution, which makes water absorption by roots more difficult; and chemical due to toxic effects, which may occur by direct action of specific ion, or by nutritional disorder (Pizarro, 1985). In this study, the more intense effect was physical because no toxicity effects or abnormalities were observed.

\section{Seedling development}

Seedling growth was affected by irrigation water salinity at both evaluation dates (32 and 77 DAS), mainly in the highest level (Figures 2 and 3 ).

At 32 DAS, there was a decrease in the number of leaves only at $\mathrm{EC}_{\mathrm{w}}$ above $4.71 \mathrm{dS} \mathrm{m}^{-1}$, when compared to $N_{1}$. According to regression equation $\hat{Y}=5.241+$ $0.289 \mathrm{EC}_{\mathrm{w}}-0.051^{* *} \mathrm{EC}_{\mathrm{w}}{ }^{2}\left(\mathrm{R}^{2}=0.91\right)$, the relative reduction at the highest $\mathrm{EC}_{\mathrm{w}}$ level $\left(\mathrm{N}_{8}\right)$ was only $22 \%$. Nevertheless, at 77 DAS the effects were intensified and $\mathrm{NL}$ decreased linearly (Figure 2), accumulating a relative reduction of about $50 \%$ at $\mathrm{N}_{8}$, more than two times higher than that of $32 \mathrm{DAS}$ at the same $\mathrm{EC}_{\mathrm{w}}$ level.

Leaf area reduction due to salinity increase occurred mostly due to change in leaf size, instead of number of leaves (Figure 2), as observed by Rhoades \& Loveday (1990). NL decreased $7.19 \%$ with per unit increase of $\mathrm{EC}_{\mathrm{w}}$ above $\mathrm{N}_{1}$, while LA decreased nearly $10.53 \%$. Morphologic adaptations, like the reduction of leaf size and number, are common when plants are under water and saline stress as a way to reduce water loss by transpiration (Shannon, 1997).

During seedling formation, until 32 DAS, the fruit tolerance to salinity was good (Figure 3). Even though the linear decreases occurred starting from $\mathrm{N}_{1}$ during this period, these were relatively small. For unit increase of $\mathrm{EC}_{w}$, relative decreases of $7.0,8.1$, and $7.6 \%$ were observed for $\mathrm{PH}$, DMS and DMR respectively, based on $\mathrm{N}_{1}$ (Figure 3). Hence, seedlings showed more than $75 \%$ of relative growth when irrigation water was of $4 \mathrm{dS} \mathrm{m}^{-1}$, considered as of "severe restriction" for most crops by Ayers \& Westcot (1991). 
At 77 DAS, salinity effects were more intense, causing more problems to seedling growth; at $\mathrm{EC}_{w}$ of 2 dS $\mathrm{m}^{-1}$, the relative reductions in $\mathrm{PH}, \mathrm{DMS}$ and DMR (based on $\mathrm{N}_{1}$ ) were $24.8,20.2$ and $19.6 \%$ respectively (Figure 3 ). These values were similar to the ones obtained with water of $4 \mathrm{dS} \mathrm{m}^{-1}$, at 32 DAS (21.0, 24.3 and $22.8 \%$ respectively). At 32 DAS, as well as at 77 DAS, there was a parallelism among curves (Figure 3 ), indicating that salinity effects on root system and aerial parts of plant were similar.

Salinity also reduced stem diameter at 77 DAS $\left(\hat{Y}=0.393-0.031^{* *} E C_{w}, R^{2}=0.92\right)$; however, the reduction was less severe compared to decreases

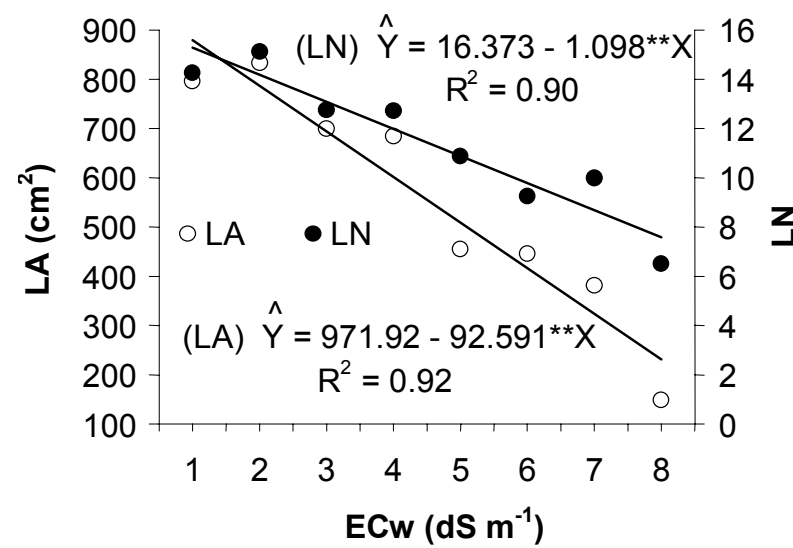

Figure 2 - Number of leaves (NL) and leaf area (LA) at 77 days after sowing as a function of irrigation water salinity $\left(E C_{w}\right)$.
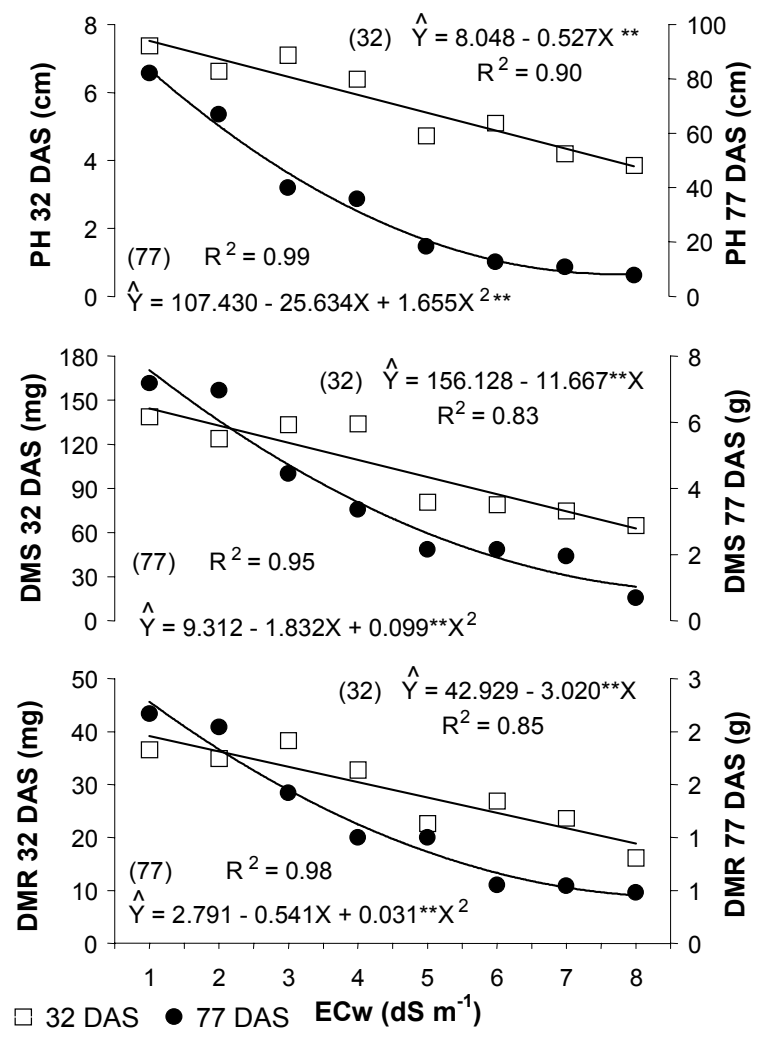

Figure 3 - Plant height (PH), dry matter of shoot and root (DMS and DMR) at 32 and 77 days after sowing (DAS) as a function of irrigation water salinity $\left(E C_{w}\right)$. observed in $\mathrm{PH}, \mathrm{DMS}$ and DMR. At $8 \mathrm{dS} \mathrm{m}^{-1}$, stem diameter was approximately $41 \%$ of the diameter at $\mathrm{N}_{1}$. Comparing the relative reduction caused by water salinity at $77 \mathrm{DAS}, \mathrm{NL}$ and diameter were the variables less affected, while more harmful effects were observed, in ascending order, on LA, DMS, DMR and $\mathrm{PH}$.

The evidences that salinity and/or sodicity affect different metabolic processes in plants, as $\mathrm{CO}_{2}$ assimilation, protein synthesis, respiration, water relations, enzymatic reactions and phytohormones conversion have been known for a long time (Menguel \& Kirkby, 1987; Shannon, 1997). These effects cause, among other problems, reduced energy availability to sustain the plant growth at satisfactory levels (Munns \& Termaat, 1986).

The intensification of salinity effects with plant age may be clearly observed by the piece meal regression analysis for the DMS data as a function of $\mathrm{EC}_{\mathrm{se}}$ at 32 and 77 DAS (Figure 4). Limiting $\mathrm{EC}_{\mathrm{se}}$ values (salinity threshold - ST) above which a decrease in DMS occurred, were 5.61 and $2.73 \mathrm{dS} \mathrm{m}^{-1}$, at 32 and 77 DAS respectively, while relative decrease rates above these limits were similar $(7.78$ and $7.44 \%$, for 32 and 77 DAS respectively), proving that the salinity effects were more drastic at 77 DAS.

In addition to salt tolerance differences among species and cultivars, differences may also exist within the same genotype group according to growth stages (Shannon, 1997).

Although salinity effects were found to intensify with plant age in this study, the results were better than expected, since Maas (1984) classified passion fruit as sensitive to salinity. Based only on ST values (77 DAS), yellow passion fruit may be classified as moderately sensitive during the seedling stage (ST between 1.3 and $3.0 \mathrm{dS} \mathrm{m}^{-1}$ ). Nevertheless, if additional criteria of the same author considered, the crop is classified as moderately tolerant, because for $\mathrm{EC}_{\mathrm{se}}=4 \mathrm{dS} \mathrm{m}^{-1} \mathrm{DMS}$ was approximately $90 \%$.

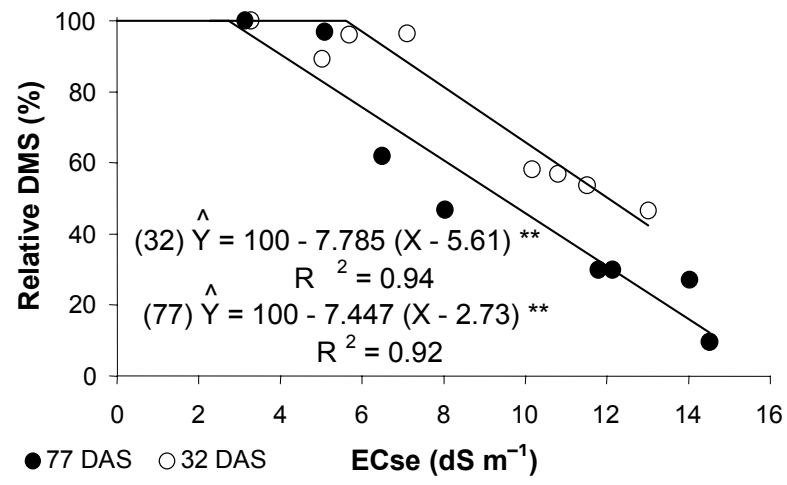

Figure 4 - Dry matter of shoot (DMS) at 32 e 77 days after sowing (DAS) as a function of electrical conductivity of saturation extract of soil $\left(E_{\mathrm{se}}\right)$. 


\section{Water consumption}

Soluble salt concentration in the root zone reduces the water flux from soil to plant and to atmosphere due to osmotic effects (Rhoades \& Loveday, 1990), reducing plant transpiration and metabolism.

In this study, the osmotic effects were responsible for the reduced plant water consumption between 33 and 77 DAS with increasing salinity levels (Figure 5A). The reduction of the evapotranspiration during the period followed a quadratic trend, similar to the discussion for $\mathrm{PH}$, DMS and DMR (77 DAS), so that the water consumption by plants at $\mathrm{N}_{8}$ was equivalent to nearly $39 \%$ that of $\mathrm{N}_{1}$, indicating that salinity stress induces water stress, with consequent growth reduction. There is a direct relationship between evapotranspiration and plant growth (Doorenbos \& Kassam, 1994). Maximum evapotranspiration, as well as maximum growth, occur when water is supplied. On the other hand, if there is water restriction, growth is reduced as observed here with increasing $\mathrm{EC}_{\mathrm{w}}$.

Considering that during the study the substrate was kept close to its maximum water retention capacity (field capacity) by frequent irrigations, the applied volumes of water in irrigation promoted frequent leaching, with no visible toxicity symptoms. The osmotic effect was probably the main cause for reduction of plant growth with increase in water/soil salinity.

No differences $(<10 \%)$ were found among saline treatments in relation to relative water consumption up to 32 DAS (Figure $5 \mathrm{~A}$ ). The germination period was 16 days, therefore, the transpiration by seedlings during the first days after germination was relatively smaller
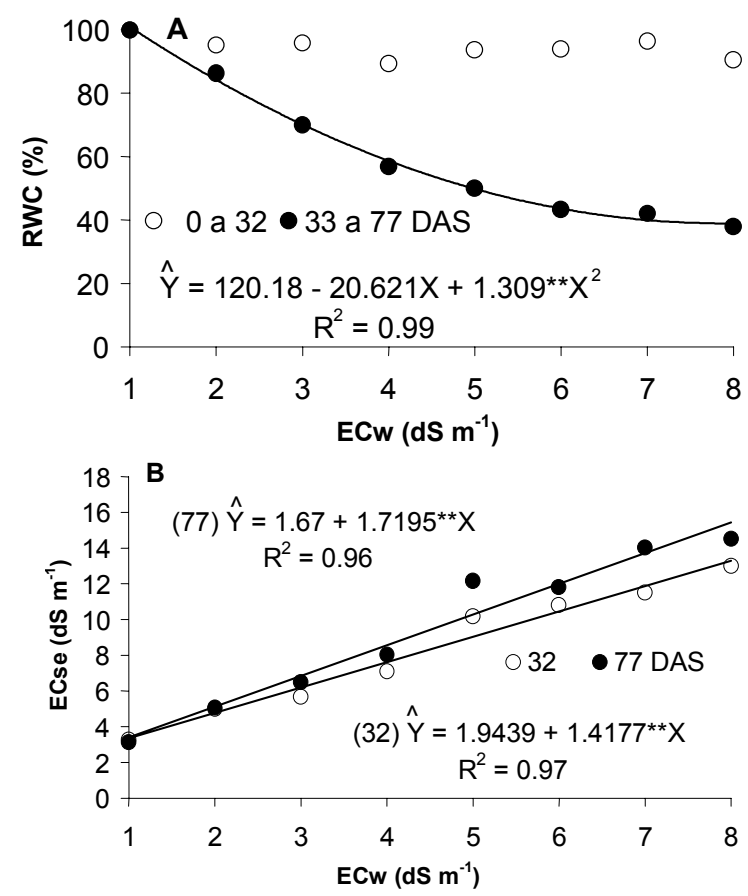

Figure 5 - Relative water consumption (RWC) accumulated for 0 - 32 and 33 - 77 days after sowing DAS (A); electrical conductivity of saturation extract of soil at 32 and 77 DAS (B) as a function of irrigation water salinity $\left(E_{w}\right)$. compared to soil surface evaporation. No substantial decrease in water consumption was observed during that period among the treatments.

Although the leaching fraction (LF) equivalent was tentatively kept around 0.4 in all treatments, for first 32 DAS the observed LF (0.43) was slightly higher than the projected value and for 33 to 77 DAS, slightly lower (0.34) but during 77 days leaching amounted $39 \%$ on average.

From the first to the second period, there was a small increase in soil salinity (Figure $5 B$ ) except for $N_{1}$, probably due to a decrease in LF. Despite the high LF, the resulting $\mathrm{EC}_{\mathrm{se}}$ values for the respective $\mathrm{EC}_{\mathrm{w}}$ treatments were higher than expected for steady-state condition (Ayers \& Westcot, 1991), mainly for the treatments with lower $\mathrm{EC}_{w}$ values, where relatively higher salt concentrations occurred. Ayers \& Westcot (1991), when estimating $\mathrm{EC}_{\mathrm{se}}$ at a specific $L F$, considered a 40:30:20:10 water extraction model in the root zone, probably not valid for this study due to limited volume of soil.

\section{Mineral composition of leaf and root}

Higher accumulation of $\mathrm{Na}, \mathrm{K}, \mathrm{Ca}$ and $\mathrm{Mg}$ was found in yellow passion fruit leaves in comparison to the roots 77 DAS (Figure 6). Na content in leaves, as well as in roots, was directly related to water salinity. Inversely, $\mathrm{K}$ amounts in leaves and roots, and $\mathrm{Ca}$ and $\mathrm{Mg}$ contents in leaves decreased with increasing salinity levels, following a quadratic trend for $\mathrm{K}$ and $\mathrm{Mg}$, and a linear for $\mathrm{Ca}$. No significant relationship was observed between $\mathrm{EC}_{\mathrm{w}}$ and contents of $\mathrm{Ca}$ and $\mathrm{Mg}$ in roots.

In saline environments where $\mathrm{Na}$ is predominant in relation to $\mathrm{K}$, plant potassium nutrition may be restrained (Schroeder et al., 1994). This suggests that the absorption mechanism for both cations is the same. Similarly, in general, $\mathrm{Na}$ ions cause disturbances in $\mathrm{Ca}$ nutrition and this nutrient has an important role in controlling the selective permeability of the plasmalema (Cramer et al., 1988).

Nutritional disturbances caused by $\mathrm{Na}$ were verified. At the lowest salinity level, $\mathrm{Na}$ and $\mathrm{Ca}$ amounts in yellow passion fruit leaves were almost equivalent (27.54 and $31.8 \mathrm{~g} \mathrm{~kg}^{-1}$ ) - Figure 6. However, for each unit increase in $\mathrm{EC}_{\mathrm{w}}$ above $\mathrm{N}_{1}$ there was a $5.56 \mathrm{~g} \mathrm{~kg}^{-1}$ increase in $\mathrm{Na}$ and at the same time, a $1.95 \mathrm{~g} \mathrm{~kg}^{-1}$ decrease in $\mathrm{Ca}$. Therefore at higher levels of water salinity there were wide differences between $\mathrm{Na}$ and $\mathrm{Ca}$ contents.

$\mathrm{K}$ absorption was more drastically reduced, even at low salinity levels. In relation to $\mathrm{N}_{1}$, the percentage decreases were 41.1, 56.8, 65.3, 70.8, 74.6, 77.4 and 79.6 for $\mathrm{N}_{2}$ to $\mathrm{N}_{8}$ treatments, respectively. For $\mathrm{Mg}$, these values were $9.8,17.9,24.7,29.9,33.5,35.6$ and $36.2 \%$, respectively.

The decrease in $\mathrm{K}, \mathrm{Ca}$ and $\mathrm{Mg}$ contents and corresponding increase in $\mathrm{Na}$ concentration in plants suggest that the plasmalema lost part of its selective ion 
absorption capacity. Probably, Na displaced Ca from the plasmatic membrane to intercellular spaces, reducing selective permeability of root thereby allowing an increase in $\mathrm{Na}$ absorption in detriment to $\mathrm{K}, \mathrm{Ca}$ and $\mathrm{Mg}$, as reported by Lacan \& Durand (1995).

The unit increase in $\mathrm{EC}_{\mathrm{w}}$ caused an increase of 53.9 and $142 \%$ in $\mathrm{Na} /(\mathrm{Ca}+\mathrm{Mg})$ and $\mathrm{Na} / \mathrm{K}$ ratios in leaves, respectively, in relation to $\mathrm{N}_{1}$ (Figure $7 \mathrm{~A}$ ). As a result, there was reduction in plant growth, decrease in DMS, increase in $\mathrm{Na}$ concentration (Figure 7B) and decrease in $\mathrm{K}, \mathrm{Ca}$ and $\mathrm{Mg}$ contents in the plant (Figure $7 \mathrm{C}$ ).

Although $\mathrm{Na}$ increased with increasing salinity, no visual toxicity symptoms were detected. Plants were probably able to find a reasonable adjustment, directing the excess $\mathrm{Na}$ to the vacuole, a mechanism for salinity tolerance described by Poljakoff-Mayber \& Lerner (1993). Yet, the nutritional disorder caused by $\mathrm{Na}$ contributed to
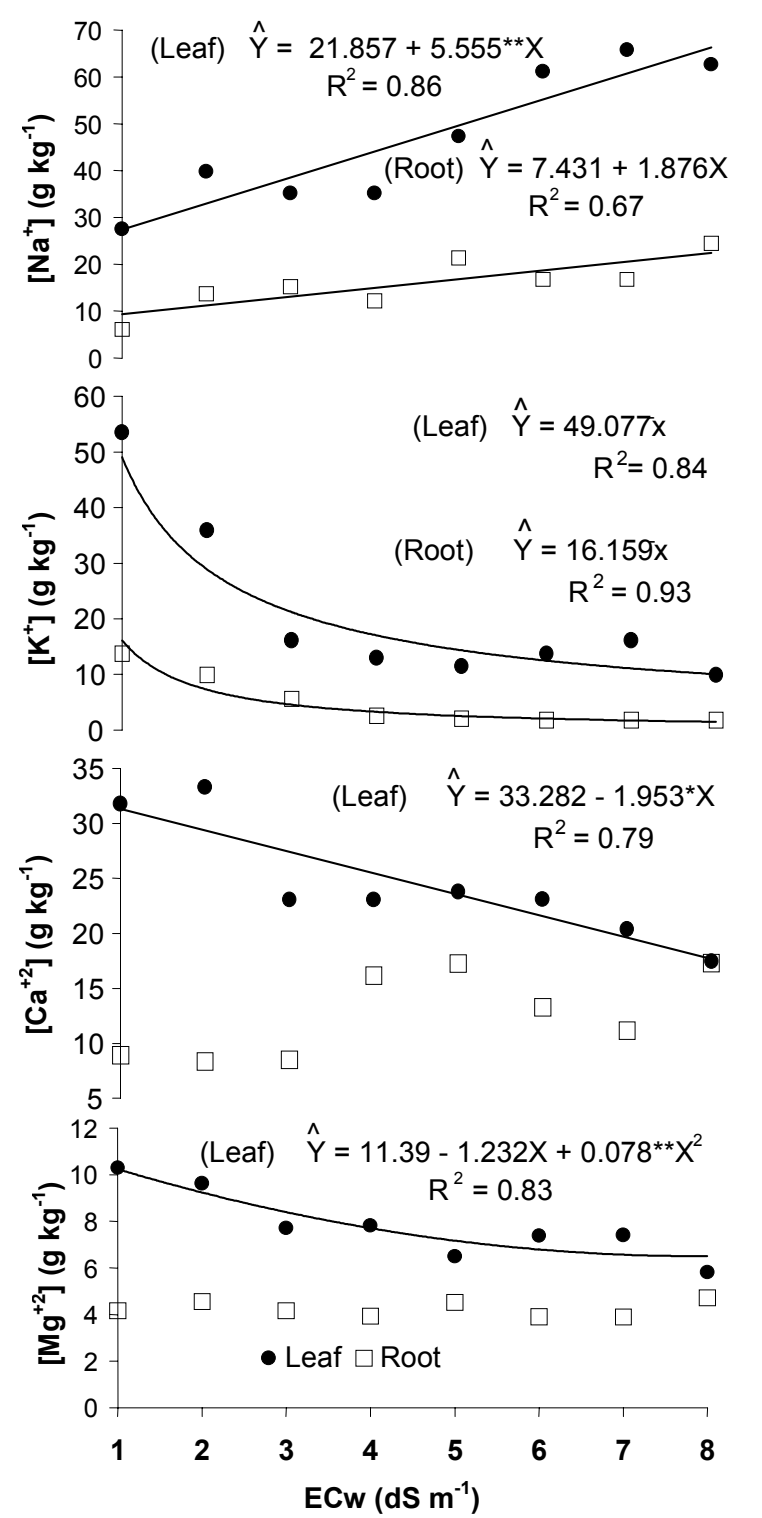

Figure 6 - Contents of $\mathrm{Na}, \mathrm{K}, \mathrm{Ca}$ and $\mathrm{Mg}$ in passion fruit leaves and roots 77 days after sowing (DAS), as a function of irrigation water salinity $\left(\mathrm{EC}_{\mathrm{w}}\right)$. reduction of plant growth with salinity, due to the essentiality of $\mathrm{Ca}, \mathrm{Mg}$ and $\mathrm{K}$ to plants.

Maintenance of adequate $\mathrm{K}$ amounts in plants is essential for growth (Wignarajah, 1995) as K activates more than 50 enzymes, some of them involved in phosphorylation reactions, carbohydrate and protein synthesis and respiration, being also essential for transport of carbohydrates and distribution to the various plant organs. $\mathrm{Mg}$ is vital to the photosynthetic process, especially because it constitutes $2.7 \%$ by weight, the chlorophyll molecule and activate various enzymes. Ca, which has another important function of maintaining selective permeability of plasma membrane.

Among the interrelated factors that influence plant's ability to tolerate saline conditions, are the sensitivity of the genotype to show Ca deficiency induced by $\mathrm{Na}$, and the ability to maintain adequate $\mathrm{K}$ levels while growing under conditions of high concentration of $\mathrm{Na}$ in soil (Grieve \& Fujiyama, 1987).

The selective ionic absorption mechanism gives the plant the capacity to discriminate between similar elements like $\mathrm{Na}$ and $\mathrm{K}$. It is an important characteristic in the adaptation process to salinity as observed by Shannon \& Noble (1995) in subterranean clover varieties (Trifolium subterraneum L.), which showed, under saline conditions,
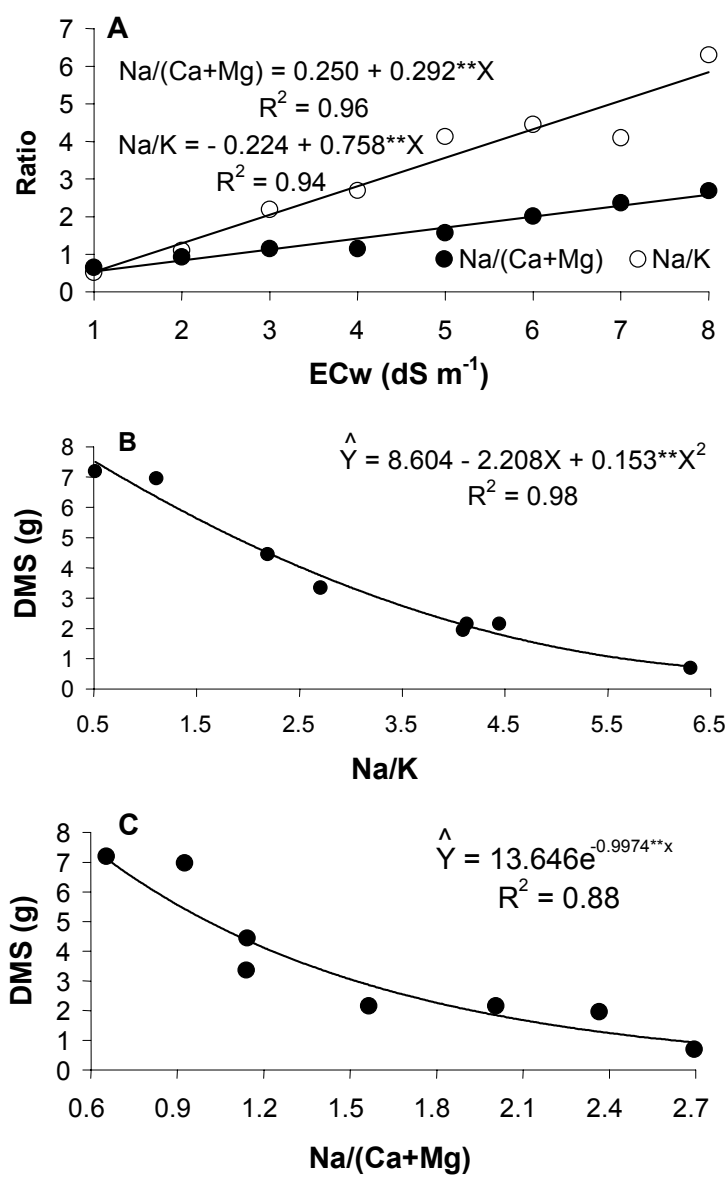

Figure $7-\mathrm{Na} / \mathrm{K}$ and $\mathrm{Na} /(\mathrm{Ca}+\mathrm{Mg})$ ratio in plant leaf as a function of water salinity $\left(\mathrm{EC}_{\mathrm{w}}\right)$ and dry matter of shoot (DMS) 77 days after sowing. 
low $\mathrm{Na}$ concentration and satisfactory $\mathrm{K}$ levels in leaves. Similarly, low $\mathrm{Na} / \mathrm{K}$ ratio in grains and leaves of salt tolerant plants have been observed (Ashraf \& O'Leary, 1996); therefore the ability to maintain $\mathrm{Na} / \mathrm{K}$ ratio less than 1.0 has been considered as a characteristic of salt tolerant plants (Bottacin et al., 1984). Passion fruit seedling were able to keep this index up to $\mathrm{EC}_{\mathrm{w}} 1.6 \mathrm{dS} \mathrm{m}^{-1}$ (Figure $7 A)$.

Regarding the relative decrease of DMS as a function of $E C_{\text {se }}$, if water of $E C_{w}<4.0 \mathrm{dS} \mathrm{m}^{-1}$ is adequately managed to maintain $E C_{\mathrm{se}}<8 \mathrm{dS} \mathrm{m}^{-1}$, it may be used to produce yellow passion fruit seedlings with a maximum growth reduction of $50 \%$. In addition, there is growth recovery later, in the field, mainly if planting is performed during the rainy season or if irrigation water used is of low to moderate salinity, as reported by Costa et al. (1986) for coconut palm.

\section{CONCLUSIONS}

Salinity effects intensified with plant age, and $\mathrm{EC}_{\mathrm{se}}$ threshold values for passion fruit seedlings were 5.61 and $2.73 \mathrm{dS} \mathrm{m}^{-1}$ at 32 and $77 \mathrm{DAS}$, respectively and a mean decrease of $7.6 \%$ per unit increase of $E_{\text {se }}$ is observed above this level.

The increase in $\mathrm{Na} / \mathrm{K}$ and $\mathrm{Na} /(\mathrm{Ca}+\mathrm{Mg})$ ratios in the plant caused by salinity is a limiting factor to plant growth.

Yellow passion fruit is tolerant to salinity during the germination stage and moderately tolerant during seedling phase.

\section{AKNOWLEGMENTS}

To CNPq, for supporting this study under the Program for Graduate Studies and Research of the Northeast (PNPGP)

\section{REFERENCES}

ASHRAF, M.; O'LEARY, J.W. Response of some newly developed salt-tolerant genotypes of spring wheat to salt stress: II. Water relations and photosynthetic capacity. Acta Botany Neerlandica, v.45, p.29-39, 1996.

AYERS, R.S.; WESTCOT, D.W. A qualidade da água na agricultura. Campina Grande: UFPB, 1991. 218p. (Estudos FAO. Irrigação e Drenagem, 29)

AZIMOV, R.A. Effects of calcium on dehydrogenase activity in cotton seed germinated in chloride salinity. Voprozy Solensteichivast Rastenii, v.1, p.181-188, 1973.

BERNARDO, S. Impacto ambiental da irrigação no Brasil. In: SILVA, D.D.; PRUSKI, F.F. (Ed.) Recursos hídricos e desenvolvimento sustentável da agricultura. Brasília: MMA; SRH; ABEAS; Viçosa: UFV, Depto. Eng. Agrícola, 1997. 252p.

BOTTACIN, A.; CACCO, G.; SACCOMANI, M. Nitrogen absorption and assimilation in $\mathrm{NaCl}$-resistant and $\mathrm{NaCl}$-susceptible millet genotypes (Pennisetum americanum). Canadian Journal of Botany, v.63, p.517520,1984
BOURSIER, P.; LAUCHLI, A. Growth responses and mineral nutrient relations of salt-stressed sorghum. Crop Science, v.30, p.1226-1233, 1990.

BRASIL. Programa de apoio e desenvolvimento da fruticultura irrigada do Nordeste. Brasília: Ministério da Agricultura e do Abastecimento, 1998. 148p.

COSTA, R.G.; PASSOS, E.E.M.; GHEYI, H.R. Aplicação de água salina na irrigação de plantas jovens de coqueiro (Cocos nucifera L.) Aracajú: EMBRAPA, CNCo. 1986. 5p. (Circular, 37)

CRAMER, G.R.; ALBERICO, G.J.; SCHMIDT, C. Salt tolerance is not associated with the sodium accumulation of two maize hybrids. Australian Journal of Plant Physiology, v.21, p.675-692, 1994.

CRAMER, G.R.; EPSTEIN, E.; LAUCHLI, A. Kinetics of root elongation of maize in response to short-term exposure to $\mathrm{NaCl}$ and elevated calcium concentration. Journal of Experimental Botany, v.39, p.1513-1522, 1988.

DOORENBOS, J.; KASSAM, A.H. Efeito da água no rendimento das culturas. Campina Grande: UFPB, 1994. 306p. (Estudos FAO. Irrigação e Drenagem, 33)

EMPRESA BRASILEIRA DE PESQUISA AGROPECUÁRIA. Manual de análise de solo. 2.ed. rev. Rio de Janeiro: EMBRAPA, CNPS, 1997. 212p.

FERREIRA, P.V. Estatística experimental aplicada à agronomia. Maceió: UFAL; EDUFAL; FUNDEPES, 1996. 437p.

GRIEVE, C.M.; FUJIYAMA. H. The response of two rice cultivars to external $\mathrm{Na} / \mathrm{Ca}$ ratio. Plant and Soil, v.103, p.245-250, 1987

LACAN, D.; DURAND, M. $\mathrm{Na}^{+}$and $\mathrm{K}^{+}$transport in excised soybean roots. Physiologia Plantarum, v.93, p.132-138, 1995.

MAAS, E.V. Crop tolerance. California Agriculture, v.38, p.20-21, 1984

MAAS, E.V.; HOFFMAN, G.J. Crop salt tolerance-current assessment Journal of Irrigation and Drainage Division, v.103, p.115-134, 1977.

MALAVOLTA, E.; VITTI, G.C.; OLIVEIRA, S.A. Avaliação do estado nutricional das plantas: princípios e aplicações. 2ed. Piracicaba: Potafós, 1997. 201p.

MARINHO, J.F.L.; FERNANDES, P.D.; GHEYI, H.R. Desenvolvimento inicial do abacaxizeiro cv. Smooth Cayenne, sob diferentes condições de salinidade da água. Revista Brasileira de Engenharia Agrícola e Ambiental, v.2, p.1-5, 1998.

MEDEIROS, J.F. Qualidade de água de irrigação e evolução da salinidade nas propriedades assistidas pelo 'GAT' nos estados de RN, PB e CE. Campina Grande, 1992. 173p. Dissertação (Mestrado) - Centro de Ciência e Tecnologia, Universidade Federal da Paraíba.

MENGUEL, K.; KIRKBY, E.A. Principles of plant nutrition. 4.ed. Bern: International Potash Institute, 1987. 687p.

MUNNS, R.; TERMAAT, A. Whole-plant responses to salinity. Australian Journal of Plant Physiology, v.13, p.143-160, 1986.

PEREIRA, J.R. Solos salino sódicos. In: REUNIÃO BRASILEIRA DE FERTILIDADE DO SOLO, 15., Campinas, 1982. Anais. Campinas: SBCS, 1983. p.127-143

PIZARRO, F. Drenaje agrícola y recuperacion de suelos salinos. Madrid: Editora Agrícola Española, 1985. 542p.

POLJAKOFF-MAYBER, A.; LERNER, H.R. Plants in saline environments. In PASSARAKLI, M. Handbook of plant and crop stress. New York: Marce Dekker, 1993. cap.4, p.65-96.

RHOADES, J.D.; LOVEDAY, J. Salinity in irrigated agriculture. In: STEWART, D.R.; NIELSEN, D.R. (Ed.) Irrigation of agricultural crops. Madison: ASA; CSSA; SSSA, 1990. p.1089-1142. (Agronomy, 30).

SCHROEDER, J.I.; WARD, J.M.; GASSMANN, W. Perspectives on the physiology and structure of inward-rectifying $\mathrm{K}^{+}$channels in higher plants: Biophysical implications for $\mathrm{K}^{+}$uptake. Annual Review of Biophysics and Biomolecular Structure, v.23, p.441-471, 1994.

SHANNON, M.C. Adaptation of plants to salinity. Advances in Agronomy, v.60, p.75-120, 1997

SHANNON, M.C.; NOBLE, C.L. Variation in salt tolerance and ion accumulation among subterranean clover cultivars. Crop Science, v.35, p.798-804, 1995.

SOUZA, R.F.A. Germinação e desenvolvimento inicial de plantas de melão (Cucumis melo L.) e melancia (Citrullus vulgaris) sob diferentes salinidades da água de irrigação. Campina Grande, 1999. 96p. Dissertação (Mestrado) - Centro de Ciências e Tecnologia, Universidade Federal da Paraíba.

VIANA, S.B.A.; FERNANDES, P.D.; GHEYI, H.R. Germinação e formação de mudas de alface em diferentes níveis de salinidade de água. Revista Brasileira de Engenharia Agrícola e Ambiental, v.5, p.259-264, 2001 WIGNARAJAH, K. Mineral nutrition of plants. In: PESSARAKLI, M. (Ed.) Handbook of plant and crop physiology. New York: Marcel Dekker, 1995. p.193-222.

Received February 16, 2001 